\title{
Molecular and Biochemical Characterization of Cotton Epicuticular Wax in Defense Against Cotton Leaf Curl Disease
}

\author{
Muhammad Azmat Ullah Khan *, Ahmad Ali Shahid, Abdul Qayyum Rao, Kamran Shehzad Bajwa, Tahir \\ Rehman Samiullah, Adnan Muzaffar, Idrees Ahmad Nasir, Tayyab Husnain
}

National Center of Excellence in Molecular Biology, 87- west canal bank road, University of the Punjab, Lahore, Pakistan

${ }^{*}$ Corresponding author: Muhammad Azmat Ullah Khan, National Center of Excellence in Molecular Biology 87- west canal bank road, University of the Punjab, Lahore, Pakistan. Tel: +92-3218897425, Fax: +92-4235293149, E-mail: mazmatullahkhan@yahoo.com

Received: May 15, 2015; Revised: October 22, 2015; Accepted: November 20, 2015

Background: Gossypium arboreumis resistant to Cotton leaf curl Burewala virus and its cognate Cotton leaf curl Multan beta satellite (CLCUBuV and CLCUMB). However, the G. arboreum wax deficient mutant (GaWM3) is susceptible to $\mathrm{CLCuV}$. Therefore, epicuticular wax was characterized both quantitatively and qualitatively for its role as physical barrier against whitefly mediated viral transmission and co-related with the titer of each viral component (DNA-A, alphasatellite and betasatellite) in plants.

Objectives: The hypothesis was the $C L C u V$ titer in cotton is dependent on the amount of wax laid down on plant surface and the wax composition.

Materials and Methods: The wax was isolated by decoction method and analysed by GC-MS whereas viral particles were quantified by Real-Time PCR. The whitefly feeding assay was performed on plant in Hoagland solution with $1 \%$ Nile Blue Dye and color was observed in the gut of whiteflies.

Results: Analysis of the presence of viral genes, namely alphasatellite, betasatellite and DNA-A, via real-time PCR in cotton species indicated that these genes are detectable in G. hirsutum, G. harknessii and GaWM3, whereas no particle was detected in $G$. arboreum. Quantitative wax analysis revealed that G. arboreum contained $183 \mu \mathrm{g} . \mathrm{cm}^{-2}$ as compared to GaWM3 with only $95 \mu \mathrm{g} . \mathrm{cm}^{-2}$. G. hirsutum and G. harknessii had $130 \mu \mathrm{g} . \mathrm{cm}^{-2}$ and $146 \mu \mathrm{g} . \mathrm{cm}^{-2}$, respectively. The GCMS results depicted that Lanceol, cis was $45 \%$ in G. harknessii. Heptadecanoic acid was dominant in G. arboreum with 25.6\%. GaWM3 had 18\% 1,2,-Benenedicarboxylic acid. G. hirsutum contained 25\% diisooctyl ester. The whitefly feeding assay with Nile Blue dye showed no color in whiteflies gut fed on G. arboreum. In contrast, color was observed in the rest of whiteflies.

Conclusions: From results, it was concluded that reduced quantity as well as absence of (1) 3-trifluoroacetoxytetradecane, (2) 2-piperidinone,n-|4-bromo-n-butyl|, (3) 4-heptafluorobutyroxypentadecane, (4) Silane, trichlorodocosyl-, (5) 6Octadecenoic acid, methyl ester, and (6) Heptadecanoicacid,16-methyl-,methyl ester in wax could make plants susceptible to $C L C u V$, infested by whiteflies.

Keywords: Cotton; GaWM3; GC-MS; Leaf curl; Wax mutant; Whitefly

\section{Background}

Plant viruses are major hindrance in yield improvement and productivity of plant products. Viruses that belong to family Geminiviridae, are economically important and transmitted by the members of the phylum Arthropoda (1).

Cotton plants are naturally affected by many stresses from which $75 \%$ are biotic (2). Among these pathogens, Cotton leaf curl virus ( $\mathrm{CLCuV}$ and its cognate $\mathrm{CLCuBuV}$ and $C L C u M B$ ) is a common source of tension for cotton growers especially in Pakistan. $C L C u V$ genome consists of a single stranded DNA particle i.e. DNA-A along with each of its associated DNA satellites, called alpha satellite and beta satellite (3).

The first and foremost physical barrier in plant pathogen interaction is epicuticular wax (4). This layer not only hinders the bacteria and fungi, but also create a first line of defense against insects (5). For instance, in wax deficient pea mutants the aphid spends more time (6). Wax can be defined as a polyester matrix of hydroxyl- and hydroxyl epoxy fatty acids $\mathrm{C}_{16}$ and $\mathrm{C}_{18}$ long (cutin) embedded and overlaid with epicuticular wax.

The Asiatic G. arboreum is resistant to $C L C u V(7)$. 
Our hypothesis was to investigate that whether the wax plays a critical barrier in transmission of $C L C u V$ by whitefly (Bemisia tabaci) in this plant. In 2009, a wax deficient mutant (GaWM3) of Asiatic G. arboreum with $50 \%$ less wax was produced (8).

\section{Objectives}

The aims of the present study was (1) to quantify the cuticular waxes and determine the biochemical composition of wax mutant GaWM3 in comparison with G. arboreum, G. hirsutum and G. harknessii, and (2) to determine the $C L C u V$ titer and its correlation with quantity and composition of waxes through feeding of whiteflies on plants.

\section{Materials and Methods}

\subsection{Plant Materials}

Seeds of G. hirsutum less waxy and susceptible to $C L C u V, G$. arboreum, "desicotton" resistant to $C L C u V$ with more epicuticular wax, G. harknessii, more waxy like and susceptible to $C L C u V$ were planted along with wax deficient mutant of G. arboreum (GaWM3) in pots as well as in field. Upward or downward curling of the leaves, thickened veins and growth of plants was noted in inoculated and non-inoculated plants as indicated by Khan et al. (9).

\subsection{CLCuV Titer Evaluation}

Viruliferous whiteflies (100) were incubated overplants. Field trials have been conducted under natural infection condition with uncharacterized $C L C u V$ isolates. However, it was found that $C L C u B V$ was more dominant in the field than $C L C U M B$ Primers were designed for alpha satellite (FR873751.1), beta satel-

Table 1. Designing of primers and probe to detect DNA-A, alphasatellite and betasatellite

\begin{tabular}{lr}
\hline DNA-A: Amplicon size $\mathbf{1 8 2}$ bp Tm: $\mathbf{5 5}{ }^{\circ} \mathbf{C}$ \\
\hline CP-F & 5'AAACAACAGGCATGGACAAA'3, \\
CP-R & 5'CCGACACCACGAGTAACATC '3 \\
CP-P & Fam-5'TGGGCCTTCACAACCCTTTGG '3-Tamra \\
\hline Alphasatellite:Amplicon size 192 bp: $\mathbf{5 5}{ }^{\circ} \mathbf{C}$ \\
\hline Alpha Rep-F & 5'GTCTTCCGACGAGTTAAGGC '3 \\
Alpha Rep-R & 5'GTCTCTGGCAAAGGTGGATT '3 \\
Alpha Rep-P & Fam-5'AACGGGACCCAGATGACCGC '3-Tamra \\
\hline Betasatellite: Amplicon size 186 bp: 55 ${ }^{\circ} \mathbf{C}$ \\
\hline BetaC1-F & 5'TTCCTATTCGCATACAACGG '3 \\
BetaC1-R & 5'ATGCATTGCTGGTTTGTGTT '3 \\
BetaC1-P & Fam-5'ACGGTTCGATTACATCCATTCCCAA'3-Tamra \\
\hline
\end{tabular}

lite (HF567946.1) and DNA-A (X98995.1). The primers and probe (5' Fam and 3' Tamra) were designed from coat protein of DNA-A, C1 region of beta-satelliteand Rep gene of alpha-satellite (Table 1) using "Genscript" website software (https://www.genscript. com/ssl-bin/app/primer). The experiment was performed in 3 replicates. The reaction mixture $(25 \mu \mathrm{L})$

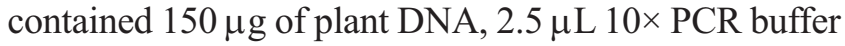
(Fermentas, USA), $2.5 \mu \mathrm{L}$ of $2 \mathrm{mM}$ dNTPs, $1.5 \mu \mathrm{L}$ of $\mathrm{MgCl}_{2}$ (Fermentas, USA) $1 \mu \mathrm{L}$ of 10 pmol. $\mu \mathrm{L}^{-1}$ each forward and reverse primers (Table 1) and $0.5 \mu \mathrm{L}$ of $5 \mathrm{U}$ Taq DNA-polymerase (Fermentas, USA). The PCR was initiated at $95^{\circ} \mathrm{C}$ for $5 \mathrm{~min}$, followed by 35 cycles of $95^{\circ} \mathrm{C}$ for $30 \mathrm{~s}, 59^{\circ} \mathrm{C}$ for $30 \mathrm{~s}$, and $72^{\circ} \mathrm{C}$ for $30 \mathrm{sec}$ with final extension at $72^{\circ} \mathrm{C}$ for $10 \mathrm{~min}$. The concentrations of the viral particles were calculated through Real TimePCR using standard curve through known standards of DNA-A, alpha satellites and beta satellites.

\subsection{Wax Quantification}

The isolation of plant epicuticular wax was performed according to "Decoction" method (10) and leaf surface area was calculated with Adobe Photoshop (11). The total isolated wax from each plant was converted into $\mu \mathrm{g}$ and divided by total leaf surface area (in $\mathrm{cm}^{2}$ ).

$$
\text { Wax per unit area }=\frac{\text { Weight of wax }(\mu \mathrm{g})}{\text { Total leaf surface area }\left(\mathrm{cm}^{2}\right)}
$$

\subsection{Determination of Biochemical Composition of Epicuticular Wax}

Gas chromatograph mass spectrometry: wax samples $(1 \mu \mathrm{g})$ in 3 replicates were dissolved in hexane and passed through impregnated carbon filter to remove any impurities. Internal standard, tetracosane $\left(10 \mu \mathrm{g} . \mu \mathrm{L}^{-1}\right)$ was added to the testing samples prior to analysis. From the wax samples, $2 \mu \mathrm{L}$ was taken and injected into the column at $50^{\circ} \mathrm{C}$ and condition was held for $2 \mathrm{~min}$. The samples were desorbed by increasing the temperature by $40^{\circ} \mathrm{C} \cdot \mathrm{min}^{-1}$ to $200^{\circ} \mathrm{C}, 2 \mathrm{~min}$ at $200^{\circ} \mathrm{C}, 3^{\circ} \mathrm{C} \cdot \mathrm{min}^{-1}$ to $310^{\circ} \mathrm{C}$, and $30 \mathrm{~min}$ at $310^{\circ} \mathrm{C}$. The Helium gas was used as the carrier and the gas flow was maintained at $2 \mathrm{~mL} \cdot \mathrm{min}^{-1}$. The quantitative composition of the mixtures was studied by capillary GC (Agilent; $30 \mathrm{~m} \mathrm{HP}-1,0.32-\mathrm{mm}$ i.d. $\mathrm{df}=1 \mu \mathrm{m}$ ) and flame ionization detection under the same GC conditions as above but Helium (carrier gas) inlet pressure was programmed for $50 \mathrm{kPa}$ at injection, held for 5 min, raised with $3 \mathrm{kPa} \cdot \mathrm{min}^{-1}$ to $150 \mathrm{kPa}$ and held for $40 \mathrm{~min}$ at $150 \mathrm{kPa}$. Single compounds were quantified 
against the internal standard by manually integrating peak areas (12). Components were identified by the help of NIST library, 2005 (13).

\subsection{Whitefly Feeding Assay}

Two week old seedling of plants (i.e. G. arboreum, GaWM3, G. hirsutumand G. harknessii) were placed into Hoagland's solution (14) with 1\% Nile Blue (Sigma Aldrich, USA). The whiteflies (Bemisia tabaci) were incubated on plants for 3 days and observed under microscope (Zeiss, Imager A1) to observe the color of Nile Blue dye in their gut.

\section{Results}

\subsection{Detection of $C L C u V$}

Symptoms: The plants were exposed to whiteflies in random in field trials and 100 whiteflies per plant were incubated in greenhouse tests. The symptoms of cotton leaf curl disease appeared on $G$. hirsutum, $G$. harknessii and GaWM3 but not on G. arboreum. The typical symptoms of upward or downward curling of the leaves and thick enation were appeared on G. hir- sutum and GaWM3 (Figure 1). The CLCuV components (alpha satellite, beta satellite and DNA-A) were quantified by real time PCR. The mean numbers of molecules per microliter of alpha satellite in betweengreenhouse and field samples were $5.9 \times 10^{8}, 4.8 \times 10^{7}$ and $4.6 \times 10^{7}$ for G. hirsutum, GaWM3 and G. harknessii, respectively. Whereas no alpha satellite was detected in G. arboreum (Figure 2A). Beta satellites were determined as $7.2 \times 10^{8}, 3.6 \times 10^{7}$ and $3.8 \times 10^{7}$ molecules. $\mu \mathrm{L}^{-1}$ in G. hirsutum, GaWM3 and G. harknessii, respectively. Similarly, beta satellite was not detected in G. arboreum (Figure 2B). The copy numbers of DNA-A in $G$. hirsutum, GaWM3 and G. harknessii were $8.7 \times 10^{8}, 6.6 \times 10^{7}$ and $6.3 \times 10^{7}$ molecules. $\mu \mathrm{L}^{-1}$, respectively. Again, DNA-A was not detected in $G$. arboreum (Figure 2C). In experimental plants, G. hirsutum: GaWM3: G. harknessii: G. arboreum, the ratio of $\alpha$-satellite was 270:24:23:0 for alpha satellite, for beta satellite was 360:18:19:0, and for DNA-A was 290:22:21:0, respectively.

\subsection{Epicuticular Wax per Unit Area}

Maximum wax per unit area was obtained from $G$.
$\mathbf{A}$

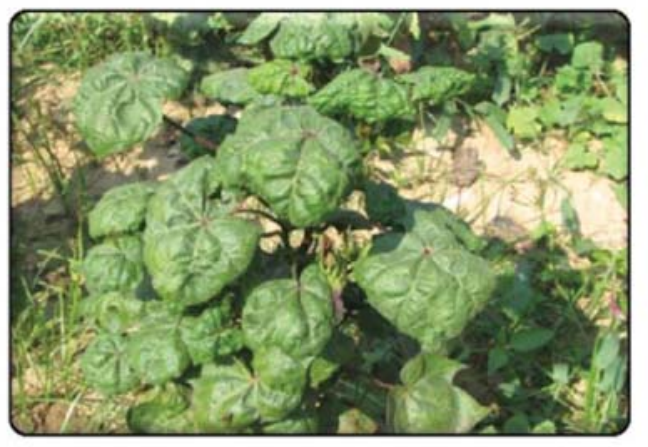

C

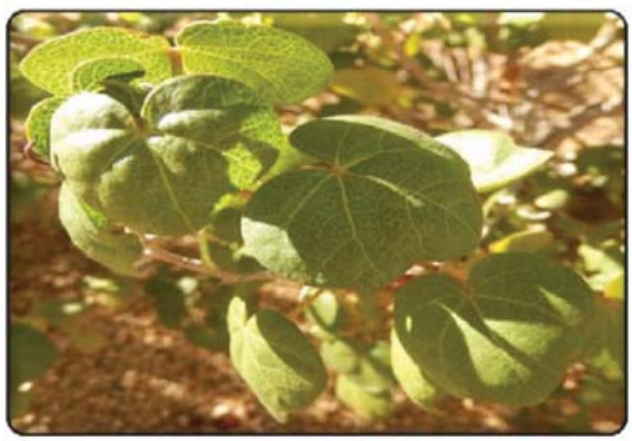

B

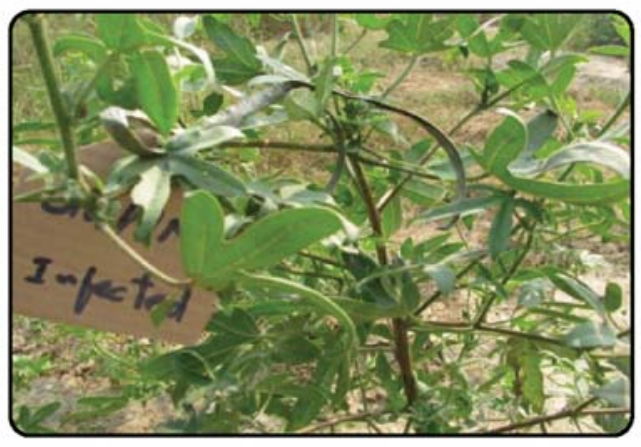

D

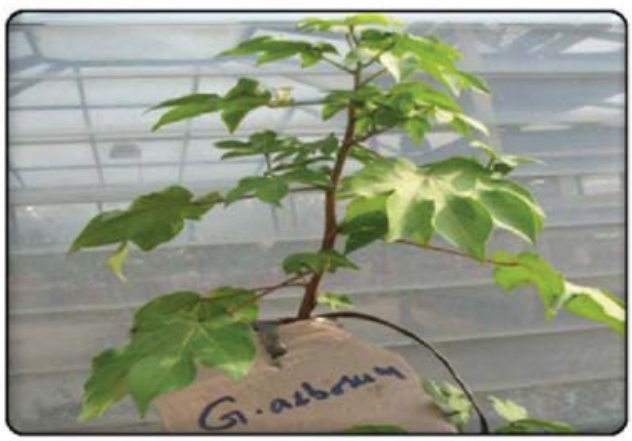

Figure 1. Symptoms on experimental plants after incubation of whiteflies A: severe symptoms were observed in G. hirsutum B: GaWM3 showed mild symptoms of upward curling C: mild symptoms of downward curling were also observed in G. harknessii D: no symptoms were observed on G. arboretum leaves 
A
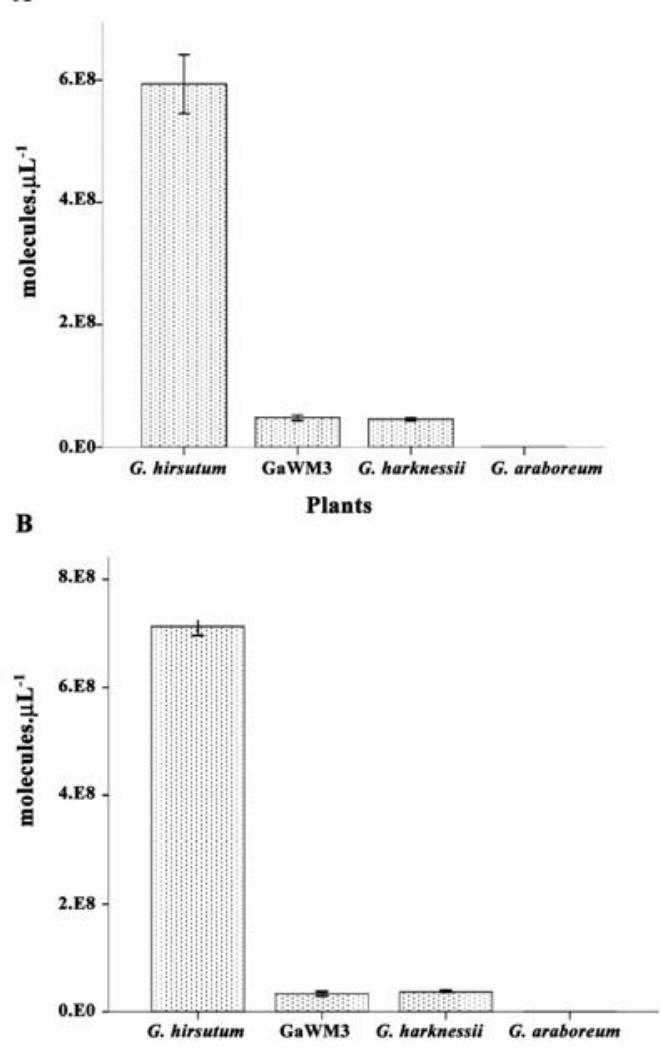

C

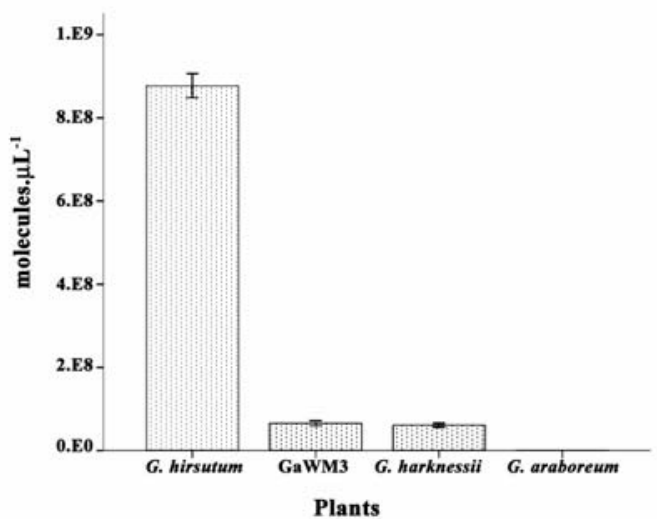

Figure 2. Real Time PCR to determine viral titer A: molecules. $\mu \mathrm{L}^{-1}$ of b-satellite was maximum in G. hirsutum, while it was not detectable in $G$. arboreum. B: molecules. $\mu \mathrm{L}^{-1}$ of $\beta$-satellite was maximum in $G$. hirsutum, while it was not detectable in $G$. arboreum C: molecules. $\mu \mathrm{L}^{-1}$ of DNA-A was maximum in G. hirsutum, while it was not detectable in G. arboreum whereas the error bars represent the variation among 3 replicates

arboreum $\left(183 \mu \mathrm{g} . \mathrm{cm}^{-2}\right)$ as compared to its mutant that had $95 \mu \mathrm{g} . \mathrm{cm}^{-2}$. In contrast, G. hirsutum and G. harknessii had130 $\mu \mathrm{g} . \mathrm{cm}^{-2}$ and $146 \mu \mathrm{g} . \mathrm{cm}^{-2}$, respectively.

\subsection{Biochemical Composition of Epicuticular Wax}

Gas chromatograph mass spectrometry of plants (G. arboreum, GaWM3, G. hirsutum and G. harknessii (Figure $3 \mathrm{~A}-\mathrm{D}$, respectively) was carried out to determine the biochemical composition of wax and their quantitative values. The chemical compounds were identified by comparing their retention time in the NIST mass spectra library, 2005 (13).

The top 3 compounds that were dominant in $G$. arboreumare suspected to be (1) $25.6 \%$ heptadecanoicacid, 16-methyl-, methyl ester (2) $14.1 \%$ phenol, 2,5-bis [1,1- dimethyl] and (3) 10.12\% 1,2-benzenedicarboxylic acid, diisooctyl ester. The dominant compounds in wax of GaWM3 were suspepcted to be (1) $18 \% 1,2$,- benenedicarboxylic acid, diisooctyl ester (2) 14\% octadecane, 1-|2-(hexadecyloxy)ethoxy|- (3) 12\% 7,9-Di-tet-butyl-1-oxaspiro $(4,5)$ deca-6, 9-diene2,8-dione and (4) 11\% nonadecane having percentage. The three major compounds found in the wax of $G$. hirsutumwere (1) 25\% 1,2-benzenedicarboxlic acid, diisooctylester (2) 21\% nonadecane and (3)14\% phenol, 2,5-bis (1,1-dimethyletyhly)- with percentage of, Lanceol, cis- and caryophyllene were the two major wax compounds found in $G$. harknessii, having the percentage of $45 \%$ and $36 \%$, respectively. Comparison of wax biochemical composition of experimental plants is shown in (Table 2).

\subsection{Whiteflies Feeding Assay}

Collected whiteflies on G. arboreum, similar to the negative control did not show any gut coloring (Figure 4 A,B), while on the other 3 plants, gut color was observed (Figure $4 \mathrm{C}-\mathrm{D}$ ).

\section{Discussion}

Here, a cotton wax mutant (GaWM3) next to 3 other wild type cotton species were analyzed to establish the role of wax in resistance against insects. The plant having less wax is more susceptible to insects, $G$. arboreum wax deficient mutant (GaWM3) was found susceptible to $C L C u V$ (Figure 2) as opposed to the wild type (7).

The concentration of the isolated waxes were 183 , 146, 130 and $95 \mu \mathrm{g} . \mathrm{cm}^{-2}$ in G. arboreum, G. harknessii, G. hirsutum and GaWM3, respectively. The concentration of the wax was in accordance with the report of Bondada et al. (15) i.e. from $70 \mu \mathrm{g} . \mathrm{cm}^{-2}$ to $154 \mu \mathrm{g} . \mathrm{cm}^{-2}$ from normal condition to stress conditions in cotton.

The results of virus symptoms appearance were in accordance with (16) and (17). The role of beta satellite 

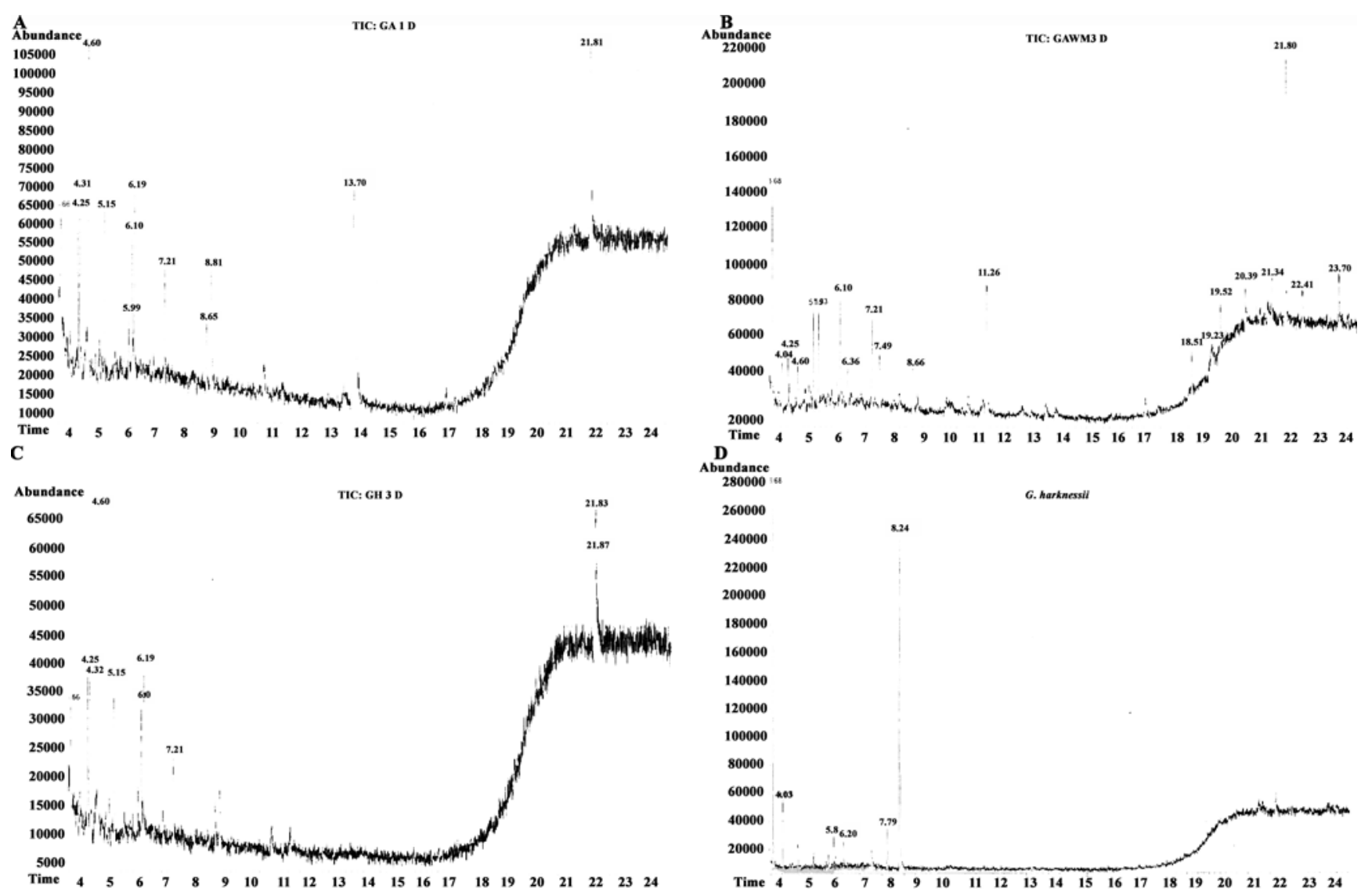

Figure 3. GC-MS TIC (total ion current trace) analysis for the compounds present in isolated wax of A: G. arboreum. B: GaWM3 C: G. hirsutum D: G. harknessii. Compounds were identified on the basis of the retention time through NIST library

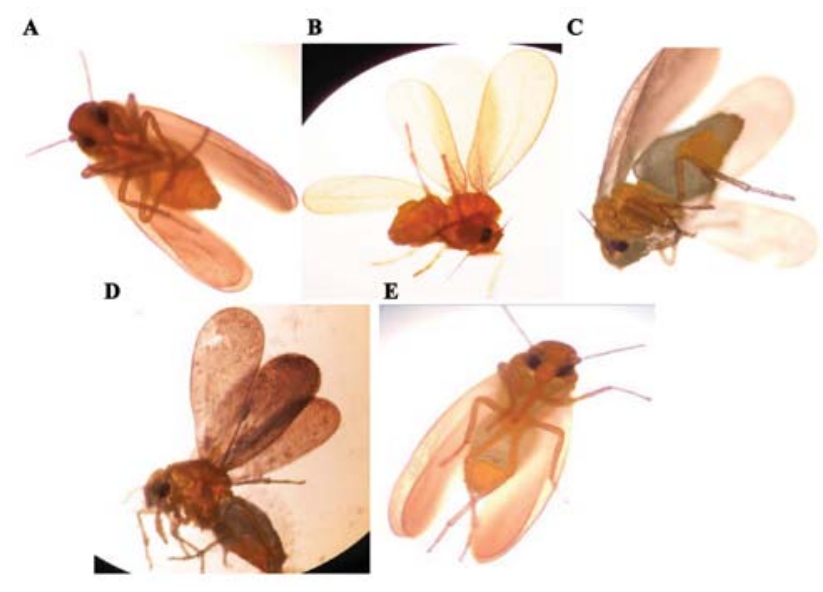

Figure 4. Whiteflies feeding assay. Whiteflies under light microscope when fed on nile blue containing experimental plants A: negative control B: G. arboreum C: GaWM3 D: G. harknessii E: G. hirsutum. Dye was observed in the gut of whiteflies fed on G. hirsutum, G. harknessii and GaWM3 whereas no color was observed in negative control and the whiteflies fed on G. arboreum is well-defined in suppressing the phyto-immune system that ultimately results in development of severe viral symptoms $(18,19)$. Our data support this hypothesis that increase in quantity of beta satellite results in increase of symptoms and vice versa. The positive correlation was found in the severity of the symptoms and titer of beta satellite particles along with DNA-A (Figure 1).

The ratio of different organic compounds varies in the epicuticular wax. Hydrocarbons, alcohols and acids were the major compounds found in the wax of red vine (Brunnichia ovata) and trumpet creeper plants (Campsis radicans) (20). In addition to these classes of compounds, esters, phenols and other aromatic compounds were also found in this study. The most dominant compounds were esters in G. arboreum, GaWM3 and $G$. hirsutum $(25.6 \%, 18 \%$ and $25 \%$, respectively) and lanceol, cis (45\%) was dominant in G. harknessii.

The comparison of wax components of GaWM3 and G. arboreum clearly demonstrated that the follow- 
Table 2. Comparison of chemical compounds present in experimental plants

\begin{tabular}{|c|c|c|c|c|c|}
\hline Sr. No & Biochemical Compounds & G. arboreum & GaWM3 & G. hirsutum & G. harknessii \\
\hline 1 & 2-cyclopentene-1-ol, 1-phenyl- & + & - & + & - \\
\hline 2 & Nonadecane & + & + & + & - \\
\hline 3 & 3-trifluoroacetoxytetradecane & + & - & - & - \\
\hline 4 & Phenol, 2,5-bis [1,1-dimethyl] & + & + & + & - \\
\hline 5 & Methoxyacetic acid, 2-tridecylester & + & + & - & - \\
\hline 6 & 2-piperidinone, n-[4-bromo-n-butyl] & + & - & - & - \\
\hline 7 & 4-heptafluorobutyroxypentadecane & + & - & - & - \\
\hline 8 & Tetradecane, 2,6,10-trimethyl- & + & + & + & - \\
\hline 9 & Silane, trichlorodocosyl- & + & - & - & - \\
\hline 10 & 6-Octadecenoic acid, methyl ester & + & - & - & - \\
\hline 11 & Heptadecanoic acid, 16-methyl-, methyl ester & + & - & - & - \\
\hline 12 & 1,2-Benzenedicarboxylic acid, diisooctyl ester & + & + & + & - \\
\hline 13 & Caryophyllene & - & + & - & + \\
\hline 14 & $\alpha$-Caryophyllene & - & + & - & + \\
\hline 15 & Hexadecane & - & + & - & - \\
\hline 16 & Eicosane, 2-methyl- & - & + & - & - \\
\hline 17 & Diethyl phthalate & - & + & - & - \\
\hline 18 & 7,9-Di-tet-butyl-1-oxaspiro[4,5] deca -6, 9-diene-2,8-dione & - & + & - & - \\
\hline 19 & Ethanol, 2-[octadecyloxy] & - & + & - & - \\
\hline 20 & $\begin{array}{l}\text { A-D-Glucopyranoside, methyl-2-[acetylamino]-2-deoxy-3-O- } \\
\text { [trimethylsillyl]-,cyclic methyl bronate }\end{array}$ & - & + & - & - \\
\hline 21 & Octadecane, 1-|2-[hexadecyloxy]ethoxy|- & - & + & - & - \\
\hline 22 & $15,17,19,21$ - Hexatriacontatetrayne & - & + & - & - \\
\hline 23 & $\begin{array}{l}\text { |5-[3-methoxymethoxy-10,13-dimethyl-2,3,4,9,10,11,13,14,15,16,17- } \\
\text { dodecahydro-1Hcyclopenta|a|[phenanthren-17-yl]-hex-1-ynul|-trime }\end{array}$ & - & + & - & - \\
\hline 24 & 2-Trifluoroacetoxyteradecane & - & - & + & - \\
\hline 25 & Trichloroacetic acid, hexadecylester & - & - & + & - \\
\hline 26 & P-Xylenolpthalein & - & - & + & - \\
\hline 27 & Lanceol, cis- & - & - & - & + \\
\hline 28 & $\begin{array}{c}\text { Napthalene, 1,2,3,4,4a,5,6,8a-octahydro-7-methyl-4-4methylene-1- } \\
{[1 \text {-methylethyl],[1 } \alpha, 4 a \beta, 8 \mathrm{a} \alpha]-}\end{array}$ & - & - & - & + \\
\hline 29 & $\begin{array}{c}\text { 2,6,10-dodecatriene-1-ol,3,7,11-tromethyl-acetate,[E,E]- 2,6,10- } \\
\text { dodecatriene-1-ol,3,7,11-tromethyl-acetate,[E,E]- }\end{array}$ & - & - & - & + \\
\hline 30 & $\begin{array}{l}\text { 2-napthalenemethanol,decahydro- } \alpha, \alpha, 4 a-t r i m e t h y l-8-m e t h y l e n e- \\
\qquad,\left|2 \mathrm{R}-\left[2^{\alpha}, 4 \mathrm{a} \alpha, 8 \mathrm{a} \beta\right]\right|-\end{array}$ & - & - & - & + \\
\hline
\end{tabular}

+ : present

-: absent

ing six organic compounds were only present in $G$. arboreum: 3-trifluoro acetoxy tetra decane, 2-piperidinone, n-[4-bromo-n-butyl], 4-heptafluorobutyroxypentadecane, silane, trichlorodocosyl-, 6-octadecenoic acid, methyl ester, and heptadecanoic acid, 16methyl-, methyl ester,may create unique features in its wax and may be involved in its resistance against transmission of $C L C u V$ (Table 2). The whitefly feeding assay also suggested that the quantity as well as quality of the wax has its role in feeding of whiteflies (Figure 4).

\section{Conclusions}

The characterization of cotton epicuticular wax and its role in transmition of $\mathrm{CLCuV}$ by whiteflies to plants were demonstrated. It was found that $50 \%$ reduction in wax (in leaves of GaWM3) made it possible for the whiteflies to transmit the virus and to develop the relevant symptoms. It is concluded that wax act like barrier in hindering the $C L C u V$ transmission in cotton. Moreover, quantities as well as chemical composition of wax had impacts on feeding behavior in whiteflies and transmission of $C L C u V$.

\section{Acknowledgements}

This study was the part of the $\mathrm{PhD}$ research that was funded by Higher Education Commission of Pakistan (HEC) conducted at Center of Excellence in Molecular Biology, University of the Punjab. 


\section{References}

1. Aftab B, Shahid MN, Riaz S, Jamal A, Mohamed BB, Zahur M, Aftab M, Rashid B, Husnain T. Identification and expression profiling of CLCuV-responsive transcripts in upland cotton (Gossypium hirsutum L.). Turkish J Biol. 2014;38(2):226237. DOI:10.3906/biy-1307-55

2. Mansoor S, Briddon RW, Zafar Y, Stanley J. Geminivirus disease complexes: an emerging threat. Trends Plant Sci. 2003;8(3):128-134. DOI: 10.1016/j.tplants.2006.03.003

3. Mubin M, Mansoor S, Hussain M, Zafar Y. Silencing of the AV2 gene by antisense RNA protects transgenic plants against a bipartite begomovirus. Virology J. 2007;4(10):1-4.

4. Carver TL, Gurr SJ. 12 Filamentous fungi on plant surfaces. Annu Plant Rev.2008;23:368.

5. Eigenbrode SD, Espelie KE. Effects of plant epicuticular lipids on insect herbivores. Ann Rev Entomol. 1995;40(1):171-94. DOI: 10.1146/annurev.en.40.010195.00 1131

6. Chang GC, Neufeld J, Durr D, Duetting PS, Eigenbrode SD. Waxy bloom in peas influences the performance and behavior of Aphidius ervi, a parasitoid of the pea aphid. Entomol Exp Appl. 2004;110(3):257-265. DOI: $10.1111 / \mathrm{j} .0013-8703$. 2004.00142.x

7. Zafar Y, Mansoor S, Asad S, Briddon R, Idrees M, Khan WS. Genome Characterization of whitefly-transmitted geminivirus of cotton and Development of Virus-resistant Plants through Genetic Engineering and conventional Breeding. ICAC Recorder USA. 2003;12-16.

8. Barozai MYK, Husnain T. Development and characterization of the asiatic desi cotton (Gossypium arboreum L.) leaf epicuticular wax mutants. Pak J Bot. 2014;46(2):639-643.

9. Khan MAU, Shahid AA, Rao AQ, Kiani S, Ashraf MA, Muzaffar A, Husnain T. Role of epicuticular waxes in the susceptibility of cotton leaf curl virus (CLCuV). Afr J Biotechnol. 2011;10(77):17868-17874. DOI: 10.5897/ AJB11.2199

10. Khan Y. Studies of wax genes in cotton. Lahore, Pakistan: University of the Punjab; Thesis dissertation. 2009.

11. Easlon HM, Bloom AJ. Easy Leaf Area: Automated Digital Image Analysis for Rapid and Accurate Measurement of Leaf Area. Appl Plant Sci. 2014;2(7):1400033. DOI: hhhttp:// dx.doi.org/10.3732/apps.1400033

12. Aharoni A, Dixit S, Jetter R, Thoenes E, van Arkel G, Pereira A. The SHINE clade of AP2 domain transcription factors activates wax biosynthesis, alters cuticle properties, and confers drought tolerance when overexpressed in Arabidopsis. Plant Cell. 2004;16(9):2463-2480. DOI: http://dx.doi.org/10.1105/ tpc. 104.022897

13. Wang F, Zhang P, Qiang S, Xu LL. Interaction of Plant Epicuticular Waxes and Extracellular Esterases of Curvularia eragrostidis during Infection of Digitaria sanguinalis and Festuca arundinacea by the Fungus. Int $J$ Mol Sci. 2006;7(9):346-357. DOI: 10.3390/i7090346

14. Asher CJ, Edwards DG. Modern Solution Culture Techniques. In: Läuchli A, Bieleski R, editors. Inorg Plant Nutr. Encyclopedia of Plant Physiology. Springer Berlin Heidelberg. 1983;15:p.94-119.

15. Bondada BR, Oosterhuis DM, Murphy JB, Kim KS. Effect of water stress on the epicuticular wax composition and ultra- structure of cotton (Gossypium hirsutum L.) leaf, bract, and boll. Environ Exp Bot. 1996;36(1):61-69. DOI: 10.1007/9783-642-68885-0_4

16. Sattar MN, Kvarnheden A, Saeed M, Briddon RW. Cotton leaf curl disease-an emerging threat to cotton production worldwide. J Gen Virol. 2013;94(Pt 4):695-710. DOI: 10.1099/vir. 0.049627-017

17. Ali I, Amin I, Briddon RW, Mansoor S. Artificial microRNAmediated resistance against the monopartite begomovirus Cotton leaf curl Burewala virus. Virol J. 2013;10(1):231. DOI: $10.1186 / 1743-422 X-10-23118$

19. Zaffalon V, Mukherjee SK, Reddy VS, Thompson JR, Tepfer M. A survey of geminiviruses and associated satellite DNAs in the cotton-growing areas of northwestern India. Arch Virol. 2012;157(3):483-495. DOI: 10.1007/s00705-011-1201-y

19. Amin I, Hussain K, Akbergenov R, Yadav JS, Qazi J, Mansoor S. Suppressors of RNA silencing encoded by the components of the cotton leaf curl begomovirus-beta satellite complex. Mol Plant-Microbe Interact. 2011;24(8):973-983. DOI: http://dx.doi.org/10.1094/MPMI-01-11-000120

20. Chachalis D, Reddy KN, Elmore CD. Characterization of leaf surface, wax composition, and control of red vine and trumpet creeper with glyphosate. Weed Sci. 2009;49:156-163. DOI: http://dx.doi.org/10.1614/0043-1745(2001)049[0156: COLSWC]2.0.CO;2 